\title{
UNIMANUAL SKILLS AS HAND LATERALIZATION PREDITCTORS
}

\author{
Milena Cvetković ${ }^{1}$, Perica Vasiljević ${ }^{2}$ \\ ${ }^{1}$ Elementary School "Sreten Mladenović Mika" Niš, Serbia \\ ${ }^{2}$ Department of Biology and Ecology, Faculty of Sciences and Mathematics, \\ University of Niš, Serbia
}

\begin{abstract}
Summary. The skill of writing with the left or right hand is often taken as a hand lateralization predictor. Taking into consideration that such a manifestation is usually practiced, left-handedness often becomes "concealed", making it harder to be phenotypically measured. The aim of this study is to determine the predictability of multiple manual skills in relation to the type of handedness. The sample of 756 primary-school students with the aid of Edinburgh Handedness Inventory showed that writing and drawing skills using a particular hand have a very clear mutual correlation ( 0.86 with the left-handed, and 0.50 with the right-handed). However, the correlation was not determined with other observed unimanual skills, such as throwing, using scissors, using a tooth brush, using a key and holding a glass. In addition to that, writing as such is not a reliable hand lateralization predictor. In relation to hand lateralization, writing shows a low determination coefficient with the left-handed, whereas for other skills R2 varies within the range $0.43-0.66$. The numbers are similar to the righthanded, where R2 varies within the range $0.28-0.53$, for all skills, except writing and drawing. A conclusion can be drawn that writing is not a reliable predictor of lateralization to left or right, but that those are skills in relation to which there is no cultural pressure.
\end{abstract}

Key words: hand lateralization, lateralization predictors, left-handedness/right-handedness.

\section{Introduction}

A general observation of scientists in the field of hand lateralization shows that approximately $90 \%$ of people are right-handed, which means that around $10 \%$ of people are left-handed (McManus, 2009), which might imply the effect of balance selection, under the influence of which such a type of polymorphism could sustain. Even though lefthandedness is observed in all societies, regardless of religion, ethnicity or other affiliation, the data on percentage distribution of left-handed/right-handed differs in great detail. The most probable cause is the difference in variables and tasks used to determine the type of handedness, which could lead to difficulties in comparing populations in relation to hand dominance. Raymond and Pontier (2004) performed a meta-analysis of 81 studies based on the tasks of throwing and hammering in 14 countries of America, Europe, Asia, Australia and Africa. The range of left-handedness dominance was 5\%-25.9\%. Such variations exist even when hand lateralization is observed in relation to writing. On the sample of 12,000 subjects from 17 countries 2.5\%-12.8\% was left-handed (Perelle \& Ehrman, 1994). Certain studies show that this ratio in Serbia is $7.6 \%$ (Milenković, et al., 2004) based on a sample of 2,546 children, that is $9.97 \%$ based on a sample of 1,354 children (Cvetković and Vasiljević, 2015). In addition to that, left-handedness often becomes "concealed“, making it

Autor za korespondenciju: Milena M Cvetković, e-mail: mcvetkovic74@gmail.com OŠ "Sreten Mladenović Mika", 18000 Niš, Srbija

Primljeno u redakciju 20. 2. 2018, rad prihvaćen za publikovanje 26. 3. 2018. 
harder to be phenotypically measured. Until 1960, as cited by Gutwinski (2011) it was usual to encourage the left-handed to practice using their right hands primarily for writing. Teng et al., 1976, observe that there was a strong social pressure for the right hand to be used for using cutlery and writing accessories in China, which decreased the percentage of using that hand for those actions in comparison to other tasks. No data on social and familiar influence regarding e.g. throwing exists, unlike the case with e.g. writing or using a particular hand for eating (De Agostini et al., 1997; Raymond \& Pontier, 2004). Llaurens et al. (2009) consider that environmental factors can influence hand lateralization in three ways, depending on the influence type: changing the hand for certain actions (writing, e.g.), but not for other actions; reducing the level of hand preference, which reflects other actions; changing the overall hand preference, in which cases a strong pressure reflects all actions. This means that for determining left/right hand dominance, writing as the only criterion is not a reliable criterion (Rife, 1940), since there is a certain percentage of the left-handed skilled to use their right hand for writing, whereas the learned skill did not reflect other unimanual skills. Coren (2012) in his book describes four possible types of actions, in relation to hand skill: the first type of actions includes writing, drawing, throwing and other actions that require precision and certain skills. The other type of actions includes actions that require a lower level of precision, i.e. reaching actions, whereas the third type of actions includes actions which primarily require strength (power actions). The last type of actions includes bimanual actions which are required to be performed with both hands. In this sense, it is important, as cited by Coren (2012), that, while determining the handedness type only the actions that imply precise hand skills are taken into consideration.

In relation to the above mentioned, the main aim of this study was determining unimanual skills for the performance of which precision is required, as well as their mutual correlation and particular and overall influence to handedness type definition.

\section{Matherials and Methods}

\section{The sample}

The total number of examinees is 756 and it consists of 12 primary schools from the city of Nis. The sample is homogeneous regarding the type of handedness, gender and age. There are 370 left-handed examinees, and 386 right-handed examinees. All the examinees are aged 10-15 and they are divided into two age categories: there are 330 younger examinees, aged 10-12 and 426 older examinees, aged 13-15. Regarding gender, the sample is homogeneous as well, meaning that there are 354 boys and 402 girls. The average age of left-handed examinees is $12.86 \pm 1.31$ (left-handed girls $12.83 \pm 1.24$, and left-handed boys 12.79 \pm 1.50 ). The sample included 34 students practiced to use their right hands for writing, despite being born as left-handed, according to their own statements. Pertaining of this group of students to one of the two categories (left-handedness/right-handedness) was determined after analysing the results.

\section{Methods}

Aiming at determining the type of handedness (both direction and level of handedness), Edinburgh Handedness Inventory-EHI was used (Oldfiled, 1971). Based on these questionnaires, average values of seven indicators were determined: using a particular hand for writing, drawing, precise throwing (in order to hit a certain target), using scissors, using 
a tooth brush, using a key to unlock and holding a glass. Values above -1.5 to -2 for the left-handed correspond to a high level of lateralization towards right (75-100\%), whereas values 1.5 to 2 for the right-handed correspond to a high level of lateralization towards right (75-100\%). Validity was determined on the part of Alipour and Agah Haris (2007).

\section{Data Processing}

Data was processed in Excel 2010 program. The choice of statistical tests was conducted based on the research design. For the analysis of the basic results, descriptive statistics was conducted. The check of the correlation among observed variables was conducted with the aid of correlation test, whereas the significance of differences was determined using ANOVA analysis, with confidence interval of $95 \%$ and significance $\mathrm{p}<0.05$. The method of linear regression was used for testing predictor characteristics.

\section{Results}

\section{Correlation between writing skills and other unimanual skills}

The dominance of a particular hand is often considered to be the basic and only predictor of hand dominance in comparison to other unimanual skills. However, the correlation between writing skills and other skills is not necessarily expressed. Table 1 shows the correlation between seven observed parameters in relation to which the hand lateralization of left-handed examinees was determined. Writing as a skill is in expressed correlation only with drawing skill with left-handed people (0.86), but not with other parameters. However, parameters such as precise throwing, using scissors, a tooth brush or key and holding a glass express a moderately significant mutual relation (from 0.31 to 0.61 ), but not the correlation with writing skills.

The correlation between the writing and drawing processes is visible even when writing is seen as a prediction parameter for other unimanual skills with left-handed examinees (Table 2). The correlation coefficient between these two parameters (writing and drawing) is 0.86 , whereas the determination coefficient is $75 \%$. However, in relation to other dependant variables, both the correlation coefficient and determination coefficient have lower values, showing that, besides for drawing, writing is not a reliable predictor of other unimanual skills.

Table 1. Correlation of skills which determine hand lateralization with the left-handed

\begin{tabular}{ccclllll}
\hline Parameters & P & C & B & M & CE & K & CA \\
\hline P & 1 & & & & & & \\
C & $\mathbf{0 . 8 6}$ & 1 & & & & & \\
B & -0.09 & -0.04 & 1 & & & & \\
M & -0.02 & 0.02 & $\mathbf{0 . 5 2}$ & 1 & & & \\
CE & -0.01 & 0.04 & $\mathbf{0 . 4 4}$ & $\mathbf{0 . 6 1}$ & 1 & & \\
K & -0.06 & -0.04 & $\mathbf{0 . 4 0}$ & $\mathbf{0 . 4 9}$ & $\mathbf{0 . 4 4}$ & 1 & 1 \\
CA & 0.06 & -0.03 & $\mathbf{0 . 3 1}$ & $\mathbf{0 . 3 7}$ & $\mathbf{0 . 3 9}$ & $\mathbf{0 . 4 9}$ & 1 \\
\hline
\end{tabular}

Legend: P-writing; C-drawing; B-precise throwing; M-using scissors; CE-using a tooth brush;

K-using a key; CA-holding a glass 
Table 2. Writing as a predictor of other dependant variables with the left-handed

\begin{tabular}{cccrrc}
\hline Skill & $\mathrm{R}$ & $\mathrm{R}^{2}$ & $\mathrm{~F}$ & $\mathrm{t}$ & $\mathrm{p}$ \\
\hline $\mathrm{C}$ & 0.864 & 0.747 & 990.071 & 31.465 & 0.000 \\
$\mathrm{~B}$ & 0.089 & 0.008 & 2.696 & -1.641 & 0.101 \\
$\mathrm{M}$ & 0.022 & 0.000 & 0.169 & -0.411 & 0.680 \\
$\mathrm{CE}$ & 0.013 & 0.000 & 0.056 & -0.238 & 0.811 \\
$\mathrm{~K}$ & 0.055 & 0.003 & 1.033 & -1.016 & 0.310 \\
$\mathrm{CA}$ & 0.059 & 0.003 & 1.205 & -1.098 & 0.272 \\
\hline
\end{tabular}

Legend: P-writing; C-drawing; B-precise throwing; M-using scissors; CE-using a tooth brush; K-using a key; CA-holding a glass; R-level of correlation; $\mathrm{R}^{2}$-coefficient of determination; F-quotient; $\mathrm{t}$-t-test value; $\mathrm{p}$-significance of differences at the level of $\mathrm{p}<0,05$

The highest correlation coefficient with the right-handed examinees is also between the writing and drawing skills and amounts 0.50, whereas all other skills are in a low correlation with the writing skill (Table 3). Certain parameters (using a tooth brush and precise throwing, using a tooth brush and using scissors, using a tooth brush and using a key, holding a glass and using scissors) show a moderately significant mutual correlation (0.31-0.41).

Table 3. Correlation among skills which determine hand lateralization with the right-handed

\begin{tabular}{llllllll}
\hline Parameters & P & C & B & M & CE & K & CA \\
\hline P & 1 & & & & & & \\
C & $\mathbf{0 . 5 0}$ & 1 & & & & & \\
B & -0.03 & 0.05 & 1 & & & & \\
M & 0.10 & 0.13 & 0.29 & 1 & & & \\
CE & 0.07 & 0.06 & $\mathbf{0 . 3 1}$ & $\mathbf{0 . 4 1}$ & 1 & & \\
K & 0.06 & 0.07 & 0.13 & 0.21 & $\mathbf{0 . 3 0}$ & 1 & 1 \\
CA & 0.04 & 0.03 & 0.13 & $\mathbf{0 . 3 5}$ & 0.28 & 0.27 & 1 \\
\hline
\end{tabular}

Legend: P-writing; C-drawing; B-precise throwing; M-using scissors; CE-using a tooth brush; $\mathrm{K}$-using a key; CA-holding a glass

Table 4. Writing as a predictor of dependant variables with right-handed examinees

\begin{tabular}{ccrrrr}
\hline Skills & $\mathrm{R}$ & $\mathrm{R}^{2}$ & $\mathrm{~F}$ & $\mathrm{t}$ & $\mathrm{p}$ \\
\hline $\mathrm{C}$ & $\mathbf{0 . 4 9 8}$ & $\mathbf{0 . 2 4 8}$ & 127.006 & 11.269 & $\mathbf{0 . 0 0 0}$ \\
$\mathrm{B}$ & 0.028 & 0.000 & 0.307 & -0.553 & 0.580 \\
$\mathrm{M}$ & 0.096 & 0.009 & 3.588 & 1.894 & 0.058 \\
CE & 0.071 & 0.005 & 1.959 & 1.399 & 0.162 \\
K & 0.058 & 0.003 & 1.323 & 1.150 & 0.250 \\
CA & 0.044 & 0.001 & 0.756 & 0.869 & 0.384 \\
\hline
\end{tabular}

Legend: P-writing; C-drawing; B-precise throwing; M-using scissors; CE-using a tooth brush; K-using a key; CA-holding a glass; $\mathrm{R}$-level of correlation; $\mathrm{R}^{2}$-coefficient of determination; F-quotient; $\mathrm{t}$-t-test value; $\mathrm{p}$-significance of differences at the level of $\mathrm{p}<0,05$

The correlation between the writing skill and drawing skill using the right hand is visible even when writing is observed as a prediction factor for presented unimanual skills, while the determination coefficient is $25 \%$ (Table 4). Similarly to the left-handed, writing as a skill is not a reliable prediction factor for other unimanual skills, except for drawing. 


\section{The influence of unimanual skills to hand lateralization}

Hand lateralization towards left/right is determined on the basis of seven observed parameters. Tables 5 and 6 show to which degrees each of the parameters influences the overal hand lateralization.

With the left-handed examinees (Table 5), predictors of lateralization towards left are not writing and drawing, but all the other types of unimanual skills, with a significantly expressed correlation $(\mathrm{R})$ and determination coefficient $\left(\mathrm{R}^{2}\right)$.

Table 5. Hand lateralization on the sample of the left-handed

\begin{tabular}{cccrrr}
\hline Predictors HL & $\mathrm{R}$ & $\mathrm{R}^{2}$ & $\mathrm{~F}$ & $\mathrm{t}$ & $\mathrm{p}$ \\
\hline $\mathrm{P}$ & 0.023 & 0.000 & 0.185 & -0.431 & 0.667 \\
$\mathrm{C}$ & 0.029 & 0.000 & 0.287 & 0.535 & 0.593 \\
$\mathrm{~B}$ & $\mathbf{0 . 7 3 2}$ & $\mathbf{0 . 5 3 6}$ & 386.159 & 19.650 & $\mathbf{0 . 0 0 0}$ \\
$\mathrm{M}$ & $\mathbf{0 . 8 1 2}$ & $\mathbf{0 . 6 5 9}$ & 648.194 & 25.459 & $\mathbf{0 . 0 0 0}$ \\
$\mathrm{CE}$ & $\mathbf{0 . 7 6 8}$ & $\mathbf{0 . 5 9 0}$ & 481.258 & 21.937 & $\mathbf{0 . 0 0 0}$ \\
$\mathrm{K}$ & $\mathbf{0 . 7 5 7}$ & $\mathbf{0 . 5 7 3}$ & 449.368 & 21.198 & $\mathbf{0 . 0 0 0}$ \\
$\mathrm{CA}$ & $\mathbf{0 . 6 5 4}$ & $\mathbf{0 . 4 2 9}$ & 250.746 & 15.834 & $\mathbf{0 . 0 0 0}$ \\
\hline
\end{tabular}

Legend: P-writing; C-drawing; B-precise throwing; M-using scissors; CE-using a tooth brush; K-using a key; CA-holding a glass; R-level of correlation; $\mathrm{R}^{2}$-coefficient of determination; F-quotient; $\mathrm{t}$-t-test value; p-significance of differences at the level of $p<0,05$

Correlation coefficient between hand lateralization and writing is barely 0.02 , whereas the same coefficient between hand lateralization and other five observed skills is within the range from 0.65 to 0.81 , with an expressed determination coefficient (43\%-66\%), which implies their significant portion in the overall left-hand lateralization.

With right-handed examinees (Table 6), drawing and writing are not in a significant correlation with the overall hand lateralization, either ( 0.11 for writing, 0.15 for drawing). Correlation coefficient between hand lateralization and other five observed skills amounts within the range from 0.52 (the relation of overall hand lateralization and precise throwing) do 0.73 (the relation between the overall hand lateralization and using a tooth brush) with a significantly expressed determination coefficient (27\%-53\%), which indicates their significant portion in the overall hand lateralization.

Table 6. Lateralization predictors on the sample of the right-handed

\begin{tabular}{cccrrr}
\hline Predictors HL & $\mathrm{R}$ & $\mathrm{R}^{2}$ & $\mathrm{~F}$ & $\mathrm{t}$ & $\mathrm{p}$ \\
\hline $\mathrm{P}$ & 0.114 & 0.013 & 5.085 & 2.255 & $\mathbf{0 . 0 2 4}$ \\
$\mathrm{C}$ & 0.149 & 0.022 & 8.747 & 2.957 & $\mathbf{0 . 0 0 3}$ \\
$\mathrm{B}$ & $\mathbf{0 . 5 2 2}$ & $\mathbf{0 . 2 7 2}$ & 144.402 & 12.017 & $\mathbf{0 . 0 0 0}$ \\
M & $\mathbf{0 . 6 8 1}$ & $\mathbf{0 . 4 6 4}$ & 333.458 & 18.260 & $\mathbf{0 . 0 0 0}$ \\
CE & $\mathbf{0 . 7 2 9}$ & $\mathbf{0 . 5 3 2}$ & 438.944 & 20.951 & $\mathbf{0 . 0 0 0}$ \\
K & $\mathbf{0 . 6 3 7}$ & $\mathbf{0 . 4 0 6}$ & 264.024 & 16.248 & $\mathbf{0 . 0 0 0}$ \\
CA & $\mathbf{0 . 6 3 2}$ & $\mathbf{0 . 3 9 9}$ & 256.539 & 16.016 & $\mathbf{0 . 0 0 0}$ \\
\hline
\end{tabular}

Legend: P-writing; C-drawing; B-precise throwing; M-using scissors; CE-using a tooth brush; K-using a key; CA-holding a glass; R-level of correlation; $\mathrm{R}^{2}$-coefficient of determination; F-quotient; $\mathrm{t}$-t-test value; $p$-significance of differences at the level of $p<0,05$ 


\section{Discussion}

Hand lateralization for performing unimanual actions is characteristic for human population since the prehistoric times, as the newest data shows (Frayer et al., 2012, Brandler et al., 2013, Fiore et al., 2015; Cvetković et al., 2015). Taking into consideration the fact that writing is heritage of the contemporary society, as well as that the assumed relation between the left-handed and the right-handed (90\%:10\%) started appearing side by side with bipedalism with the ancestors of Homo sapiens, it is clear why certain authors (Rife, 1940) cited that writing is not a reliable criterion for determining the handedness back in the last century. Handedness was determined in relation to the writing skill (Perelle i Ehtman, 1994), but also in relation with certain other skills, such as throwing and hammering (Raymond i Pontier, 2004), making the range of percentage distribution different on the global level. Results are significantly influenced by the social pressure (Teng et al., 1976; Gutwinski, 2011), but primarily in comparison to writing and using the hand to eat, whereas the data on the same influence to other skills, such as throwing, do not exist (De Agostini et al., 1997; Raymond and Pontier, 2004). What is also interesting is the fact that throwing used to be considered as a reliable criterion for handedness determination with men, but not as a reliable criterion with women, with whom pulling thread through a needle was seen as a criterion more frequently (Rife, 1940). The presented research did not aim at determining percentage distribution of the left-handed and the right-handed on the sample, but the variables having prediction character in relation to hand lateralization. With regard to that, seven unimanual skills were observed. These skills require precision, and could indicate hand lateralization, in addition to writing. Only one dependant variable is directly related to writing skills, that skill being using the hand for drawing. Taking into consideration the fact that both writing and drawing represent practiced skills of leaving traces in the shape of symbols (letters, signs, drawings, etc), such a correlation was expected. However, writing has no prediction characteristic in relation to other observed dependant variables, neither with the left-handed, nor with the right-handed examinees (Table 2 and Table 4). The correlation between these two skills is evident (Table 1 and Table 3), but not the correlation with other observed skills. Such data implies that the writing skill is not a reliable predictor of the type of handedness, i.e. hand lateralization. This conclusion is well-represented in the example of 34 examinees of this research who practiced using their right hands for writing, and drawing consequentially. However, the other skills are not in proportional accordance with the change, making their lateralization type towards left, according to the average values of all results. Taking these reasons into consideration, other parameters were observed as well, in order to determine their prediction value. The obtained data implies that more reliable hand lateralization predictors (with the left-handed for $\mathrm{R}$ ranging from 0.65 to 0.81 and $\mathrm{R}^{2}$ ranging from 0.43 to 0.66 and for the right-handed for $\mathrm{R}$ ranging from $0.52-0.73$ and $\mathrm{R}^{2}$ ranging from 0.28 to 0.53 ) are throwing, using scissors, using a key, holding a glass and using a tooth brush. It can be concluded that writing on its own is not a reliable handedness predictor, which is implied by the data obtained by result analysis of those students who practiced their writing. In addition to that, writing (as well as drawing) using the left hand in certain societies is subject to an alteration i.e. could be influenced by culture and environment (Donaldson and Johnson, 2006). In that sense, more reliable indicators of the type of handedness are those unimanual skills to which cultural pressure was not imposed, as shown in this research. 
Acknowledgements. This work was supported by the Ministry of Education, Science and Technological Development of the Republic of Serbia, Grant No. III41017.

\section{Literatura}

Alipour, A.; Agah Haris, M. Reliability and validity of Edinburg handedness inventory in Iran. Journal of Psychological Sciences, 2007, 22: 117-133

Brandler, W. M., Morris, A. P., Evans, D. M., Scerri, T. S., Kemp, J. P., Timpson, N. J., ... \& Monaco, A. P. (2013). Common variants in left/right asymmetry genes and pathways are associated with relative hand skill. PLoS Genet, 9(9), e1003751.

Coren, S. (2012). The left-hander syndrome: The causes and consequences of left-handedness. Simon and Schuster.

Cvetković, M., \& Vasiljević, P. (2015a). Handedness and phenotypic characteristics of the head and face. Genetika, 47(2), 723-731.

Cvetković, M., Vasiljević, P., \& Najman, S. (2015b). Handedness. Glasnik Antropološkog društva Srbije, (50), 115-124.

De Agostini, M., Khamis, A. H., Ahui, A. M., \& Dellatolas, G. (1997). Environmental influences in hand preference: An African point of view. Brain and cognition, 35(2), 151-167.

Fiore, I., Bondioli, L., Radovčić, J., \& Frayer, D. W. (2015). Handedness in the Krapina Neandertals: A reevaluation. PaleoAnthropology, 2015, 19-36.

Frayer, D. W., Lozano, M., Bermúdez de Castro, J. M., Carbonell, E., Arsuaga, J. L., Radovčić, J., ... \& Bondioli, L. (2012). More than 500,000 years of right-handedness in Europe. Laterality: Asymmetries of Body, Brain and Cognition, 17(1), 51-69.

Gutwinski, S., Löscher, A., Mahler, L., Kalbitzer, J., Heinz, A., \& Bermpohl, F. (2011). Understanding lefthandedness. Dtsch Arztebl Int, 108(50), 849-53.

Llaurens, V., Raymond, M., \& Faurie, C. (2009). Why are some people left-handed? An evolutionary perspective. Philosophical Transactions of the Royal Society B: Biological Sciences, 364(1519), 881-894.

McManus, I. C. (2009). The history and geography of human handedness. Language lateralization and psychosis, 37-57.

Milenkovic, S., Kocijancic, R., \& Belojevic, G. (2004). Left handedness and spine deformities in early adolescence. European journal of epidemiology, 19(10), 969-972.

Oldfield, R. C. (1971). The assessment and analysis of handedness: the Edinburgh inventory. Neuropsychologia, 9(1), 97-113.

Perelle, I. B., \& Ehrman, L. (1994). An international study of human handedness: the data. Behavior genetics, 24(3), 217-227.

Raymond, M., \& Pontier, D. (2004). Is there geographical variation in human handedness? Laterality: Asymmetries of Body, Brain and Cognition, 9(1), 35-51.

Rife, D. C. (1940). Handedness, with special reference to twins. Genetics, 25(2), 178.

Teng, E. L., Lee, P. H., Yang, K. S., \& Chang, P. C. (1976). Handedness in a Chinese population: Biological, social, and pathological factors. Science, 193(4258), 1148-1150. 


\title{
UNIMANUELNE VEŠTINE KAO PREDIKTORI LATERALIZACIJE RUKE
}

\author{
Milena Cvetković, Perica Vasiljević
}

Sažetak. Veština pisanja levom ili desnom rukom se često označava kao prediktor lateralizacije ruke. Ako se uzme u obzir da se pisanje levom rukom često prevežbava, levorukost ostaje "zamaskirana", a time i teže fenotipski merljiva. Cilj ovog istraživanja je utvrđivanje prediktabilnosti unimanuelnih veština u odnosu na tip rukosti. Pravac rukosti 756 učenika koji su učestvovali u istraživanju, određen je Edinburg upitnikom (Edinburgh Handedness Inventory). Pokazalo se da su veština pisanja i veština crtanja određenom rukom u značajnoj korelaciji (0.86 kod levorukih i 0.50 kod desnorukih). Međutim, korelacija ove dve veštine sa drugim unimanuelnim veštinama, kao što su bacanje, korišćenje makaza, korišćenje četkice za zube, korišćenje ključa i držanje čaše, nije ustanovljena. U vezi s tim, veština pisanja sama po sebi nije dobar prediktor lateralizacije ruke. U odnosu na lateralizaciju ruke, određenu kroz sve posmatrane unimanuelne veštine, veština pisanja pokazuje slab determinacioni koeficijent kod levorukih, dok je za ostale veštine $\mathrm{R}^{2} \mathrm{u}$ opsegu $0.43-0.66$. Kod desnorukih $R^{2}$ je $0.28-0.53$, za sve veštine, osim za pisanje i crtanje. Može se izvesti zaključak da veština pisanja (time i crtanja) nije dobar prediktor lateralizacije ruke ulevo ili udesno, za razliku od ostalih posmatranih unimanuelnih veština, koje nisu pod kulturološkim pritiskom..

KIjučne reči: lateralizacija ruke, prrediktori lateralizacije, levorukost/desnorukost. 